\title{
Draft Books of Vilém Slavata of Chlum and Košumberk (1572-1652). A Publication Project ${ }^{1}$
}

JOSEF HRDLIČKA - PAVEL KRÁL

The main aim of this paper is to present a plan to publish a large collection of early modern aristocratic correspondence in the form of a critical edition. Personal letters belong among crucial historical sources, especially when the world outlook of nobility in the early modern period is studied. They often reveal unique concepts of the writer's identity, bring forth details from his or her intimate live and describe every-day, festive and ritual moments of their lives. As early modern aristocratic correspondence did not clearly distinguish between „public“ and „private“ spheres, letters of persons who came from the milieu of the imperial court in Vienna or had positions at the court or in land government also serve as a means by which to reflect political, economic, religious, social and cultural conditions of the period. ${ }^{2}$ Editions of aristocratic correspondence have a long tradition in the Czech historiography and the present edition of letters by Vilém Slavata of Chlum and Košumberk would like to continue in this approach. It will be a part of the edition series Prameny k českým dějinám 16-18. stolet $i$ [Sources of Czech History in the $16^{\text {th }}$ to $18^{\text {th }}$ centuries]. ${ }^{3}$

Originally, large corpuses of aristocratic correspondence were edited by positivist

1 In the text, English place-names are used only when commonly accepted form exists (Prague, Vienna), in other cases the names of places appear in the language of the country in which they are currently located. Proper names are used in Czech (with the exception of the names of sovereigns), family names are in slightly anglicized form of the Czech name, rather than adopting the German name, e. g. Vilém of Rožmberk (not Vilém of Rosenberg). Cf. Notes on the Text and Translation in James R. Palmitessa (ed.), Between Lipany and White Mountain. Essays in Late Medieval and Early Modern Bohemian History in Modern Czech Scholarship, Leiden-Boston 2014, pp. XIV-XV.

2 On methodological utilization of ego-sources and correspondence cf. Josef PAUSER - Martin Scheutz - Thomas Winkelbauer (edd.), Quellenkunde der Habsburgermonarchie (16.-18. Jahrhundert), Wien-München 2004, here pp. 727-1112; Winfried Schulze (ed.), Ego-dokumente. Annäherung an den Menschen in der Geschichte, Berlin 1996.

3 The edition series is a common edition project of the Institute of History of the University of South Bohemia in České Budějovice and the Institute of History of the Czech Academy of Science. The draft books of Vilém Slavata will be published in series B which is dedicated to sources of personal nature. The significance of correspondence for the series is underlined with the fact that the first volume of the series brought letter corpus of the nobility. Cf. Pavel MareK (ed.), Svédectví o ztráté starébo světa. Manželská korespondence Zdeňka Vojtěcha Popela z Lobkovic a Polyxeny z Pernštejna, České Budějovice 2005 (= Prameny k českým dějinám 16.-18. století, řada B, svazek I). The project is also one of the outputs of the research centre Habsburkové véeských dějinách which is supported by the Faculty of Arts, University of South Bohemia in České Budějovice. 
historians as early as the late $19^{\text {th }}$ century and at early $20^{\text {th }}$ century. An important role was played by the series Archiv cesky [Czech Archive, further in footnotes AČ], in which editions of letter collections of the Rožmberks and the lords of Hradec from the late $15^{\text {th }}$ century and early $16^{\text {th }}$ century, ${ }^{4}$ of the Švamberks, ${ }^{5}$ Zdeněk Lev of Rožmitál, ${ }^{6}$ of the Pernštejns ${ }^{7}$ or Karel the Elder of
Žerotín ${ }^{8}$ were published. Letters of both significant persons and ordinary nobles were made accessible to readers by the scholars. A part of the $19^{\text {th }}$ century cultural history concept, they aimed to reveal everyday lives of noblemen and noblewomen. ${ }^{9}$ A special attention was paid to women's history. ${ }^{10}$ Unique collections of correspondence by Zuzana Černín of Harasov ${ }^{11}$ and

4 Antonín Rezex (ed.), Dopisy rodi̊ Hradeckébo a Rosenberskébo od roku 1507-1519, Praha 1892 (= Archiv český 11); IDEm (ed.), Dopisy rodů Hradeckébo a Rosenberského od roku 1519 do 1526, Praha 1893 (= Archiv český 12).

5 Antonín Rezek - František Mareš - Josef Kalousek (edd.), Dopisy rodu Švamberského z let 1449-1526, Praha 1896 (= Archiv český 15).

6 František Dvors ký (ed.), Dopisy pana Zdeňka Lva z Rožmitála z let 1508-1520, Praha 1887 (=Archiv český 7); IDEM (ed.), Dopisy pana Zdeňka Lva z Rožmitála z let 1520-1526, Praha 1888 (=Archiv český 8); IDEM (ed.), Dopisy pana Zdeňka Lva z Rožmitála z roku 1526, Praha 1889 (=Archiv český 9); IDEM (ed.), Dopisy pana Zdeňka Lva z Rožmitála z let 1526-1528, Praha 1890 (=Archiv český 10); IDEM (ed.), Dopisy pana Zdeňka Lva z Rožmitála z let 1530-1532, Praha 1892 (=Archiv český 11); IDEM (ed.), Dopisy pana Zdeňka Lva z Rožmitála z let 1532-1535, Praha 1893 (= Archiv český 12).

7 Cf. František PalackÝ (ed.), Psani pana Viléma z Pernšteina od roku 1520, Praha 1840 (=Archiv český 1); IDEm (ed.), Psani pana Viléma z Pernšteina od roku 1520 a 1521, Praha 1842 (=Archiv český 2); František Dvorský (ed.), Dopisy pánưv Jana a Vojtěcha z Pernštejna 1509-1548, Praha 1902 (= Archiv český 20); IDEM (ed.), Dopisy pana Viléma z Pernšteina z let 1480-1521, Praha 1897 (=Archiv český 16); IDEm (ed.), Dodatek k dopisưm Viléma z Pernšteina z let 1496-1511, Praha 1899 (=Archiv český 17).

$8 \quad$ František Dvorský (ed.), Dopisy Karla st. ze Žerotina 1591-1610, Praha 1904 (= Archiv český 27).

9 Max Dvořák (ed.), Dva deniky Dra. Matiáše Borbonia z Borbenheimu, Praha 1896; Julius GLücKLICH (ed.), Václava Budovce z Budova korrespondence z let 1579-1619, Praha 1908; IDEM (ed.), Nová korespondence Václava Budovce z Budova z let 1580-1616, Praha 1912; Václav Schultz (ed.), Korespondence hrabète Václava Jiř́ho Holického ze Śternberka z let 1638-1674, Praha 1898; Hynek Gross (ed.), Dopisy rodu rožmberského z oboru lesnictvi, lovů a o zásilkách zvěriny, ryb a jiných potřeb ke dvoru a do kuchyně rožmberské z let 1464 do 1609, Písek 1909.

10 August SedláčEx (ed.), Listy pani Perchty Lichtenšteinské z Rožemberka, Praha 1892 (= Archiv český 11); František Dvorskŕ (ed.), Staré pisemné památky žen a dcer českých, Praha 1869.

11 František Dvorskŕ (ed.), Zuzana Černinová z Harasova. Dopisy české šlechtičny z polovice 17. století, Praha 1866; IDEm (ed.), Mateř a dcera paní Zuzany Černínové z Harasova. Listy Alžbèty Homutovny z Cimburka a Elišky Myslikovny z Chudenic, Praha 1890. Later the correspondence of the Černíns was exercised by Zdeněk Kalista (ed.), Korespondence Zuzany Černinovéz Harasova s jejím synem Humprechtem Janem Černinem z Chudenic, Praha 1941; IDEM (ed.), Korespondence cisaře Leopolda s Humprechtem Janem Černínem z Chudenic, Praha 1936. Cf. also František Tischer (ed.), Dopisy Sylvie hrab. Černinové, rozené Caretto-Millesimovy, s chotèm jejím Heřm. Hrab. Černínem z Chudenic z let 1635-1651, Praha 1908. 
Kateřina of Žerotín née of Valdštejn attracted most attention. ${ }^{12}$ Other editions collected letters from various writers. ${ }^{13}$

Spurred by Jaroslav Pánek's edition of the last Rožmberks's chronicles, ${ }^{14}$ a renewed interest in critical editions of early modern aristocratic correspondence could be observed in the 1980s. As the early modern nobility became a fundamental topic of the Czech historiography after $1989,,^{15}$ editions of aristocratic correspondence appeared, especially of the Pernštejns, ${ }^{16}$ lords of Hradec and the Rožmberks, ${ }^{17}$ of the lords of Lobkovice ${ }^{18}$ and, recently, also of some minor noble families. ${ }^{19}$ None of these collection, however, can match unique draft books of Vilém Slavata of Chlum and Košumberk.

Vilém Slavata stemmed from a Bohemian nobility whose estates were in East Bohemia. ${ }^{20} \mathrm{He}$ was born in December 1572 to Adam Slavata (1546-1616) and Dorota Slavata of Trachenberk $(\dagger 1586) .{ }^{21}$ The family belonged to the Unity of the Brethren well

12 František Dvorskŕ (ed.), Listy pani Kateriny ze Žerotina, rozené z Valdstejna I-II, Praha 1894-1895.

13 Cf. mainly František HrubÝ (ed.), Moravské korrespondence a akta z let 1620-1636 I-II, Brno 1934-1937.

14 Cf. Jaroslav PÁnex (ed.), Václav Březan, Životy poslednich Rožmberkủ I-II, Praha 1985. Although it is not a correspondence collection, Březan found the most information for his historical writing in the letters of the last two members of the Rožmberk family. Cf. also Noemi Rejchrtoví (ed.), Karel starš̌ ze Žerotina. Z korespondence, Praha 1982.

15 Cf. Václav BůžEK - Pavel KRÁl - Zdeněk VybíRAL, Der Adel in den böhmischen Ländern 1526-1740. Stand und Tendenzen der Forschung, Anzeiger der philosophisch-historischen Klasse 137, 2002, s. 55-98.

16 Petr Vorel (ed.), Česká a moravská aristokracie v polovinè 16. stoleti. Edice register listů bratři z Pernśtejna z let 1550-1551, Pardubice 1997.

17 Václav BŮžEK - Josef HRDLIČKA, Rodinný život poslednich pánů z Hradce ve svètle jejich korespondence, in: Václav Bůžek (ed.), Poslední páni z Hradce, Ceské Budějovice 1998 (= Opera historica 6), pp. 145-217; Jiří KuBEš (ed.), Rodinné vztahy pánů z Hradce a Rožmberkũ v prédbëlohorském století, in: ibidem, pp. 273-317.

P. Marek (ed.), Svédectví o ztrátè starého svèta.

19 Petr Mareš (ed.), Karel Častovec Myška ze Žlunic. Život předbëlohorského rytî̌re ve svètle rodinné korespondence, Ústí nad Labem 2000; IDEm (ed.), Korespondence Albrechta Pétipeského z Chỹš a Egrberku z let 1570-1596, České Budějovice 2015 (Prameny k českým dějinám 16.-18. století, řada B, svazek VI); Miroslav Žı ItnÝ (ed.), Korespondence Štastného Václava Pétipeského z Chýš́ a Egrberku z let 1600-1610, České Budějovice 2015 (= Prameny k českým dějinám 16.-18. století, řada B, svazek VII/1).; IDEM (ed.), Korespondence Štastného Václava Pétipeského z Chýs a Egrberku z let 1611-1621, České Budějovice 2016 (= Prameny k českým dějinám 16.-18. století, řada B, svazek VII/2).

20 Cf. older works on Vilém Slavata, mainly Josef JіRеČЕK, Leben des Obersten Hofkanzlers von Böhmen Wilhelm Grafen Slavava, Praha 1876; Josef Dobiáš, Vilém Slavata, Časopis historický 1, 1881, 269-309 (here p. 276); 2, 1882, pp. 34-56.

21 On the Slavatas cf. Antonín Rувіс̌KA, Hrad Košumberk, Památky archaeologické a místopisné 4, 1860, pp. 49-57; August SedLÁčEK, Hrady zámky a tvrze královstvi Českého I, Praha 1993², 
before the mid- $16^{\text {th }}$ century, which caused a decline in the family's prestige and property after the suppression of the first anti-Habsburg revolt in 1547. It also affected the education of the young Vilém, which he obtained at family seats in Košumberk and in Češtínkostel. ${ }^{22}$ The young nobleman was also influenced by his grandmother Alžběta Slavata of Hradec (1524-1585). It was her marriage to Diviš Slavata (1515-1575) that made the Slavatas close relatives to an influential Catholic family of the lords of Hradec. ${ }^{23}$ Family knots and property reasons caused Adam Slavata to send his son to the house of his influential and richer relative Adam II of Hradec, the Bohemian High Chancellor (1549-1596).

It is likely that in 1590-1592 Vilém and another of Adam's sons, Jáchym Oldrich, studied together in Prague. At the end of 1592, Vilém set out for a journey to Italy, where he visited Venice, Florence and probably also Rome and got matriculated at famous universities in Padova and Sienna during the next four years. On his return from the south of Europe, in 1596, he dwelt at the seats of his relatives, in Hradec or in the Prague palace of Jáchym Oldřich. It was the long-term stay in Italy, financed by his uncle Adam II of Hradec, and the pronouncedly Catholic atmosphere at the seat in Jindríchův Hradec, supported by the Jesuits, who had a college there from the mid- $16^{\text {th }}$ century, which contributed to Slavata's conversion to Catholicism in August 1597. ${ }^{24}$ The move was to be crucial for his future career. His decision coincided with an upsurge of conversions among Bohemian, Moravian and Austrian noblemen, which documents the radicalisation of the religious situation in the Habsburg monarchy at that time. ${ }^{25}$

pp. 96-103; Václav Vladimír Jeníčen, Jindřich Slavata na hradě Košumberce 1549-1599. Přebled dějin bradu i rodu, Praha 1939.

22 Martin HoLÝ, Zrozeni renesančního kavalíra. Výchova a vzdèláni šlechty z českých zemí na prahu novověku, Praha 2010, pp. 83-86; IDEM, Ve službách šlechty. Vychovatelé nobility z českých zemí (1500-1620), Praha 2011, namely pp. 200, 320.

23 V. BŮžEK (ed.), Poslední páni z Hradce.

24 Josef JiRečEк, Přestoupení Viléma Slavaty k církvi katolické, Časopis katolického duchovenstva 3, 1862, pp. 401-435; František TePLÝ, Proč se stal Vilém Slavata z Chlumu a Košumberka z českého bratra katolíkem, Sborník Historického kroužku 13, 1912, pp. 205-221; 14, 1913, pp. 25-41, 171-181. More recently Petr MAŤA, Von der Selbstapologie zur Apologie der Gegenreformation: Konversion und Glaubensvorstellungen des Oberstkanzlers Wilhelm Slawata (1572-1652), in: Ute Lotz-Heumann Jan-Friedrich Mißfelder - Matthias Pohlig (edd.), Konversion und Konfession in der Frühen Neuzeit, Göttingen 2006, pp. 287-322.

25 Thomas Winkelbauer, Fürst und Fürstendiener. Gundaker von Liechtenstein, ein österreichischer Aristokrat des konfessionellen Zeitalters, Wien-München 1999, pp. 66-158; IDEM, Karrieristen oder fromme Männer? Adelige Konvertiten in den böhmischen und österreichischen Ländern um 1600, in: Bronislav Chocholáč - Libor Jan - Tomáš Knoz (edd.), Nový Mars Moravicus aneb Sborník př́spěvků, jež věnovali Prof. Dr. Josefu Válkovi jeho žáci a přátelé k sedmdesátinám, Brno 1999, pp. 431-452; IDEM, Konfese a konverze. Šlechtické promény vyznáni v českých a rakouských zemích od sklonku 16. do poloviny 17. století, Český časopis historický 98, 2000, pp. 476-540, for Slavata pp. 513-523. 
Shortly after, Vilém Slavata set out for another foreign tour. He visited the Holy Roman Empire, the Low Countries, England, France, Spain and Italy this time. He took part in the celebrations of the beginning of Jubilee Year in Rome at the turn of December 1599 and January 1600. On that occasion he obtained the papal matrimonial dispensation for his expected marriage to his blood relative Lucie Otýlie of Hradec (1582-1633). ${ }^{26}$ The wedding took place at the castle of Jindřichův Hradec in January 1602 and two years later, after the death of her older brother Jáchym Oldřich, Lucie Otýlie became the heir to the property and to the social prestige of the lords of Hradec - together with her husband. After the Rožmberks died out in $1611,{ }^{27}$ Vilém Slavata began to foster the myth that he was the successor to the two ancient and influential Bohemian families. ${ }^{28}$
Although, until 1602, Vilém Slavata formally owned only a minor manor of Stráž nad Nežárkou in south Bohemia, he also managed other estates belonging to his wife. One of the largest aristocratic domains consisted of hereditary family manors of the lords of Hradec with their centres in Jindřichův Hradec and Telč, of the neighbouring estate of Nová Bystřice and some other smaller properties. Slavata controlled their government and, building on earlier attempts of the former owners Adam II and Jáchym of Hradec, he introduced counter-Reformation measures there. In the 1620 s he completed rapid re-Catholisation of both town and rural inhabitants in his domain. ${ }^{29}$ However, he did not profit from huge property movements which occurred in Bohemia during the property seizures after the White Mountain defeat. He only gained a traditional family manor of Košumberk which had been

26 Petr MAŤA, Oslavy jubilejního léta 1600 a česká šlechta, Jihočeský sborník historický 66-67, 1997-1998, pp. 111-117.

27 Jaroslav PÁnek, Posledni Rožmberkové - velmoži české renesance, Praha 1989; Václav BůžEk et al., Svéty poslednich Rožmberkü, Praha 2011.

28 Petr MAŤA, Zrození tradice (Slavatovské vyústění rožmberského a hradeckého odkazu), in: Václav Bůžek (ed.), Poslední páni z Hradce, pp. 513-552; Josef HrdLIčKa, Jak se utvárí pamět', in: Václav Bůžek Pavel Král (edd.), Pamět urozenosti, Praha 2007, pp. 68-87; Václav BůžEK - Stanislav DoležAL Josef HrdličKa - Miroslav NovotnÝ - Rostislav SmíšEk, Jezuitská divadelní hra Rosa Novodomensis. Zlatá a červená pétilistá rüže na zlatých hroudách jako nástroj tvorby mýtu, in: Václav Bůžek (ed.), Šlechta raného novověku pohledem českých, francouzských a španělských historikủ, České Budějovice 2009 (= Opera historica 13), pp. 263-305; Petr MAŤA, „De Rosenbergiis Bohemis plura sunt controversa. "Rožmberkové ve šlechtické pamèti 17. století, in: Jaroslav Pánek a kolektiv (edd.), Rožmberkové. Rod českých velmožů a jeho cesta dějinami, České Budějovice 2011, pp. 626-631.

29 Josef HrduičKa, Selbstverwaltung unter adeliger Herrschaft: Die Stadt Jindřrichĩv Hradec (Neuhaus) nach der Revolte gegen Wilhelm Slavata (1620-1626), in: Stefan Haas - Mark Hengerer (edd.), Im Schatten der Macht. Kommunikationskulturen in Politik und Verwaltung 1600-1950, FrankfurtNew York 2008, pp. 51-74; IDEM, Vira a moc. Politika, komunikace a protireformace v predmoderním mèstě (Jindřichưv Hradec 1590-1630), České Budějovice 2013 (= Monographia historica 14). 
seized from his non-Catholic relatives. ${ }^{30}$ $\mathrm{He}$ also held a central Bohemian estate of Mělník as a pledge in 1623-1641. ${ }^{31}$

At the very beginning of the $17^{\text {th }}$ century, Vilém Slavata started his political career. In 1604, he literary ,inherited“ the profitable office of the Lord Burgrave of Karlštejn from his deceased relative Jáchym Oldřich of Hradec. He held it till 1611 when he was forced to step down due to the pressure of the non-Catholic opposition supported by the new King Matthias. Later he obtained less important office of the Court Judge which he possessed from 1611 to 1617 . At the same time he was the President of the Bohemian Chamber in $1612-1618 .{ }^{32}$ In 1617 , shortly before the outbreak of the Bohemian Revolt, he gained the office of the High Land Judge. He was violently deprived of all offices during the Defenestration of Prague, as the non-Catholic opposition accused him of oppressing their land privileges. Having spent some time in house arrest in Prague he managed to escape from the Kingdom ruled by the non-Catholic estates and left for Passau, where he became the head of Catholic emigration. Still in exile, he was reappointed to the office of the President of the Bohemian Chamber, which he kept until 1623; he also spend the same time in the office of the High Land Judge. In 1623 he was assigned as the High Chamberlain and, a year later, he entered the Privy Council for the first time and stayed until his death. At the beginning of 1625 he voluntarily resigned from the chamberlain's office and started making his way to the sovereign's court. In 1627 and 1628, he was appointed as a member of the land government as the High Steward and in 1628 he reached the dream office of the High Chancellor which had been occupied by his three relatives from the family of Hradec in the $16^{\text {th }}$ century. He headed the Bohemian Chancery then until his death in $1652 .{ }^{33}$

Besides being an influential politician in the early $17^{\text {th }}$ century, Vilém Slavata was also the author of handwritten treatises in which he commented on contemporary events. The earliest one, dating back to 1601-1603, contains chronologically edited records about sessions and judgements of the Large Land Court of the Kingdom of Bohemia, where Slavata was a juror, and of Royal Council, where he

30 Josef HrduičKa, Zámek Košumberk a jeho slavatovští majitelé v prvni polovině 17. století, in: Emil Voráček a kolektiv (edd.), Luže v dějinách I. Od počátků středověku do konce 17. století, Luže 2010, pp. 81-95.

31 Petr KopıčKa, Správa velkostatku Mèlník v 16. až 20. století (Diplomatická studie z dẽjin patrimoniální a hospodárské správy), Porta Bohemica 2, 2003, pp. 24-78, namely pp. 31-32.

32 On his activities in the office cf. František Roubíк, Slavatưv pokus o nezávislost české komory a komoře dvorské z r. 1614, in: Sborník prací věnovaných Janu Bedřichu Novákovi k šedesátým narozeninám 1872-1932, Praha 1932, pp. 468-485.

33 Much evidence on the career of Vilém Slavata has been gathered by Petr MAŤA, Svět české aristokracie (1500-1700), Praha 2004. 
was a member. ${ }^{34}$ The records describe cases heard before the Court or at the Council and are accompanied by a description of the Bohemian Land Diet from 1603. ${ }^{35}$

The ground for another, even more extensive handwritten treatise, was the fact that Bohemian Kings Rudolph II (1552-1612) and Matthias (1557-1619) appointed Slavata to represent them at meetings of Moravian land diets, the first one being the Diet of Olomouc in June 1607. The manuscript also contains information about dramatic incidents which occurred in the Margraviate of Moravia in the following year of 1608. Slavata was then not successful in his efforts to persuade the Moravian estates to keep their loyalty to Rudolph II during the Bruderzwist. In the spring of the same year, Slavata was one of the commissioners who were to solve and settle a dispute between the Land Hetman-in-Office Ladislav Berka of Dubá († 1613) and Moravian estates; he was also a royal commissioner to the Moravian Land Diet of Brno in 1608 and to the gathering of Moravian estates in Ivančice in April of the same year. ${ }^{36}$ Another part of the manuscript is dedicated to proceedings of Moravian Land Diets from 1613, 1614 and 1615. All the seven chapters of the manuscript have a similar form. The author describes his journeys do the diets, both public and private negotiations, visits and feasts; he also includes copies of charters and other documents which were connected to the events and negotiations described. ${ }^{37}$

In the 1620s, Vilém Slavata was appointed as one of the ambassadors who should settle a dispute concerning the Duchy of Opava, first in 1614 and 1615 in Vienna and later at the General Diet of

34 Marek Starí, Přední klenot zemský. Vétš́ zemský soud království českého v dobè rudolfinské, Praha 2014, pp. 245-248.

35 The original copy of the manuscript is deposited in Státní oblastní archiv [State Regional Archive] (further SOA) Třeboň, subsidiary Jindřichův Hradec, Rodinný archiv [Family Archive] (further RA) Slavatů, inv. č. 113, sign. III A 3b, kniha č. 26. It was edited by Antonín RezeK (ed.), Zápisky Viléma Slavaty z let 1601-1603, Praha 1887.

36 On the context of these negotiations cf. Jan TENoRA, Úcast kardinála Ditrichśtejna za boje mezi arciknižetem Matyásem a Rudolfem II. roku 1608, Brno 1917; Zdeněk Vybíral, Stavovská Morava mezi Rudolfem II. a Matyásem (Vztahy mezi českou a moravskou stavorskou reprezentaci a konfederace z roku 1608), Časopis Matice moravské 116, 1997, pp. 347-386; Tomáš Knoz, Mäbren im Jabre 1608 zwischen Rudolf und Mathias, in: Václav Bủžek (ed.), Ein Bruderzwist im Hause Habsburg (1608-1611), České Budějovice 2010 (= Opera historica 14), pp. 331-362.

37 Kamil Krofta, Zápisky Viléma Slavaty o vécech moravských z l. 1607, 1608, 1613-1615, Český časopis historický 16, 1910, pp. 44-51. The manuscript is deposited in Knihovna kláštera Křižovníků s červenou hvězdou v Praze [Library of the Monastery of the Knights of the Cross with the Red Star in Prague], sign. XXI C 33; Jiř́ PrAžÁK, Katalog rukopisư křizoovnické knihovny, nyni deponovaných ve Státni knihovně ČSR v Praze, Praha 1980, pp. 96-97. As stated by Kamil Krofta, Antonín Rezek was preparing the edition, however it has never been published. The Diet of 1607 was dealt with by Jaroslav ČechuRA, Z moravského ưradováni Viléma Slavaty, in: Luděk Březina - Jana Konvičná - Jan Zdichynec (edd.), Ve znamení zemí Koruny české. Sborník k šedesátým narozeninám prof. PhDr. Lenky Bobkové, CSc., Praha 2006, pp. 142-153. 
Prague in 1615 . The conflict was initiated by Silesian estates when King Matthias assigned the Duchy to Karel of Lichtenstein as a hereditary feud..$^{38}$ Also this experience was reflected in a handwritten treatise; descriptions of individual events are supplemented with copies of documents which were connected with recorded events. ${ }^{39}$

Other Slavata's manuscripts originated in the period after the White Mountain Battle. At the beginning of the 1620s, still being in the exile in Passau, he began to draft an apology of the Society of Jesus, which he had supported extensively ever since his conversion. According to his own words, he composed the apology as a negative reaction to attacks against Jesuits which they had to face since their arrival to the country in the 1550s and which culminated with their forced departure after the outbreak of the Bohemian Revolt. Slavata rejected the reasons which had led to the exit of the Jesuits and, also, commented on the texts of both estate apologies from the years of the Revolt as well as other written attacks against the Society. ${ }^{40}$ In four volumes and many chapters, the extensive text of the apology advocates and celebrates activities of the Society in the multi-confessional society of Bohemia in the late $16^{\text {th }}$ and early $17^{\text {th }}$ centuries, described the origins of the Order as well as its spread through Europe and overseas. ${ }^{41}$

The most extensive handwritten work began to be drafted by Vilém Slavata at the break of 1636 and 1637 as a critical reaction to the memorial treatise of his political rival Jindřich Matyáš of Thurn. In the text, he justified the Defenestration of Prague in May 1618, which also affected Slavata, and the freedom of the estates to elect the King of Bohemia. In his treatise, Slavata describes in detail crucial events from 1608 to 1618 which led to the Bohemian Revolt. He could utilise both his memories of the events he had lived through and his own notes from that period. The Czech text was almost immediately translated into German and Slavata was sending individual quaternes of the incipient manuscript to his aristocratic

38 Radek Fukala, Protilichtenštejnská opozice na Opavsku v letech 1613-1617, Časopis Matice moravské 120, 2001, pp. 67-90; IDEm, Stavorská politika na Oparsku v letech 1490-1631, Opava 2004, pp. 49-64.

39 The manuscript is deposited in Národní knihovna v Praze [National Library in Prague], Oddělení rukopisů a starých tisků [Department of Manuscripts and Old Books], sign. XVII D 35. For more details see Josef Polišenský, Viléma Slavaty relace o jednáni v př́ičinè knižectví Opavského 1614-1615. Př́śpèvek k poznání politického myšlení prèedbèlohorských Čech, Slezský sborník 51, 1953, pp. 488-198.

40 Antonín Markus, Stavorské apologie z roku 1618, Český časopis historický 17, 1911, pp. 58-74, 200-217, 304-315, 421-435.

41 A Czech copy of the manuscript from the beginning of the $20^{\text {th }}$ century is deposited in SOA Třeboň, subsidiary Jindřichův Hradec, RA Slavatů, rukopisy - dodatky. More Josef SALABA, Slavatova apologie Jesuitů, Český časopis historický 4, 1898, pp. 324-332. Recently Josef HrdLičKA, Slavatova obrana jezuitského rádu a jeho predstavy o konfesijnim usporádáni Čech z pocátku dvacátých let 17. století, Folia historica bohemica 23, 2008, pp. 225-248; P. MAŤA, Von der Selbstapologie. 
friends and collected their commentaries on the text. As early as 1640, the original text became more comprehensive and the Historické spisovanni [Historical Treatise] got a wider chronological, topical and geographical scope. The original two volumes, presenting Slavata's perspective on the dramatic decade of political and religious conflict prior to the Bohemian Revolt, and which was made accessible in a later edition, ${ }^{42}$ were accompanied by more twelve volumes by $1651 .{ }^{43}$ The author traces Czech and (central)-European political, military, religious and other events, sometimes marginal, sometimes even unrelated to the main line of reading. ${ }^{44}$ The fifth volume of the Historické spisováni, outlining the $\mathrm{Czech}$ religious history from Charles IV to Ferdinand III, has been edited for print too. ${ }^{45}$

Personal records of Vilém Slavata are deposited in the archive fund Rodinný archiv Slavatu [Family archive of the Slavatas] in Státní oblastní archiv [State Regional Archive] Třeboň, Jindřichův
Hradec subsidiary. ${ }^{46}$ Together with charters issued by others for Vilém Slavata, it contains ten boxes of miscellanea. First of all these are personal deeds including the papal dispensation for his marriage to $\mathrm{Lu}^{-}$ cie Otýlie, poems written by the students of the Jesuit College in Jindřichův Hradec commemorating Slavata, drafts for the above-mentioned manuscripts, testaments or list of funeral expenses. Another part of the personal papers collection consists of family letters addressed to Vilém Slavata by his father Adam, his cousin Kryštof Štastný and another relative Jindřich Vilém. Other preserved correspondence contains letters sent to Slavata by both Czech and foreign nobles, religious dignitaries, owners of neighbouring manors or representatives of some Bohemian royal towns. An autonomous part of the personal papers collection is composed of documents which were connected with degrees and orders awarded to Slavata and with public offices he possessed, including letters written by Kings Rudolph II,

42 Josef Jirečex (ed.), Pamèti nejuyššiho kanclére Královstuí českého Viléma hrabète Slavaty I-II, Praha 1866-1868.

43 The outline of its content ibidem I, pp. 12-28.

44 Most attention have attracted parts depicting the activities of Jesuit Hieronymus Gladich who freed souls from the purgatory. Cf. P. MAŤA, Zwischen Heiligkeit und Betrügerei. Arme-Seelen-Retter, Exorzisten, Visionäre und Propheten im Jesuiten- und Karmelitenorden, in: Anna Ohlidal - Stefan Samerski (edd.), Jesuitische Frömmigkeitskulturen. Konfessionelle Interaktion in Ostmitteleuropa 1570-1700, Stuttgart 2006, pp. 177-206; IDEM, Arme-Seelen-Rettung in Presburg, 1646/47. Mikrohistorie einer Massenhysterie, in: Rudolf Leeb - Susanne Claudine Pils - Thomas Winkelbauer (edd.), Staatsmacht und Seelenheil. Gegenreformation und Geheimprotestantismus in der Habsburgermonarchie, Wien-München 2007, pp. 75-97.

45 Hanuš OpočEns KÝ (ed.), Vilém Slavata z Chlumu a Košumberka, Přehled náboženských dějin českých, Praha s. d. [1912]

46 Karel Tříska, Rodinný archiv Slavatů z Chlumu a Košumberka 1407-1728 (1780), Třeboň 1965 (the inventory of the archive fund is deposited in v SOA Třeboň, subsidiary Jindřichův Hradec). 
Ferdinand II (1578-1637), Ferdinand III (1609-1657) and their spouses. The next file of the personal documents holds official correspondence with foreign sovereigns, generals, cardinals, archbishops, representatives of religious orders, institutions and other important persons. A less extensive part of the personal papers collection is represented by documents which were connected with the administration of land property. Together with letters and charters, it also includes instructions for manor administration, castle inventories, lists of assets and liabilities, bonds and other small accounting documents like journeys expenses, purchases of clothes and kitchen necessities or various rents. Besides the above-mentioned documents, personal papers of Slavata include handwritten materials in the form of books. Together with 14 volumes of Historické spisováni, these consist of ten volumes of his correspondence preserved in the form of drafts. ${ }^{47}$ However, documents connected with Vilém Slavata can also be found in other parts of the Slavata family archive, mainly in the personal papers of his wife Lucie Otýlie and his sons Adam Pavel and Jáchym Oldřich, as well as in many other funds and collections.

As mentioned above, an extensive part of Vilém Slavata's personal papers is formed by correspondence addressed to him out of various reasons. Originals of his letters are deposited in the family archive in personal papers of his relatives and can be found in various quantity in other nobility archives, archives of various institutions or in some archive collections. However, the largest number of mail sent by Vilém Slavata can be yet found in his family archive. Nevertheless, they are not originals of his letters, but drafts. Until today, ten books of letter drafts by the Bohemian High Chancellor from 1622 to 1650 in about 1,750 pages have been preserved. The unique corpus of letters is aimed to be edited within the proposed project.

Preserved drafts of letters reveal that Slavata dictated them to a scribe; in rare cases even two recorders could take their turns in writing. ${ }^{48}$ Based on the dictation the scribe wrote a draft of a letter, i. e. the proposed version of the fair copy. Already during the dictation, or just after it had been completed, Slavata made some alternations and additions which were later included to the fair copy by the scribe. Single drafts were written into so called "quiterns" (quaternes), i. e. paper quires of ten sheets and of the size approximately $31-32 \mathrm{~cm}$ to $19.5-20.5 \mathrm{~cm}$. It is remarkable that drafts were not entered chronologically in individual quaternes. On the contrary, scribes of Vilém Slavata employed more quaternes simultaneously. Some quires were used for drafts of letters which were later sent to Slavata's closest noble friends and political fellows such as Jaroslav Bořita of Martinice (1582-1649),

47 SOA Třeboň, subsidiary Jindřichův Hradec, RA Slavatů, inv. č. 98 to 107 , kniha č. 15 to 24.

48 The praxis of Slavata's dictating to scribes and then correcting the text also in his historical treatises mentioned Antonín Rezeк (ed.), Zápisky, p. 4; Josef Jirečé (ed.), Paméti I, p. 5; Josef Polišenský, Viléma Slavaty relace, footnote 26, p. 494. 
his son Jiří Adam Bořita of Martinice (1602-1651) and also many others. Other quaternes were dedicated to regular correspondence with Slavata's oldest son Adam Pavel (1603-1657), who settled at south Bohemian family manors after his voluntary departure from the imperial court in Vienna. ${ }^{49}$ Single quaternes were established for letters addressed to administration officers of Slavata's manors, both family (Jindřichův Hradec, Košumberk, Telč) and pledge ones (Mělník). The quaternes also differed in language. Most of the draft books contain letters in Czech, only two were reserved for foreign languages - German and Italian. ${ }^{50}$ Scribes provided individual quaternes with headings, usually stating the word "Quitern“" completed with the date and place of its establishment, respectively the name of the recipient.

The fact that the quaternes contain only drafts influenced how the letters have been preserved. With some exceptions, they do not contain full address. Recipients were only shortly specified with their names („Panu z Vejtmile [To Lord of Vejmile]") or positions („Nejvyšsimu panu hofmistrovi [To the High Steward]", „Hejtmanu košumberskému [To the Hetman of Koschumberg]"). As some quaternes were dedicated to a sole recipient, the name or the position were often replaced with a demonstrative pronoun („Témuž“, „Eidem“).
Information on the date and place of origin of the draft was usually part of such a shortened ,address“. The place of origin could also be omitted, usually when Slavata dwelt at the same place for a longer period of time. The short introduction was followed by the text of the draft. At the end salute and signature, of course, were missing in vast majority of cases. The text of letters was usually concluded with simple „S tím zưstávám [Yours faithfully]“ or even shorter „Zưstávám [Yours]“, many times just replaced with a scribe's abbreviation. Drafts were written only to the right side of the page. When it was full, the scribe turned the sheet 90 degrees counter clockwise and continued filling the so far empty left side of the page lengthwise.

Later, we do not know when exactly, the quaternes of drafts of the correspondence of Vilém Slavata were bound into books. Altogether ten draft books have been preserved. Each of them is endowed with a hard paper cover of dimension 33 to $21 \mathrm{~cm}$. The cover features a white oval label with a Latin numeral stating the number of the draft book (I to X) and the time span of drafts contained. A black cloth spine of each book was completed with a white paper label stating the name of the archival institution where the draft books are deposited, the abbreviation of the archival fund (RAS) and the inventory number of the book (15 to 24). Having

49 The originals of the letters of Vilém Slavata to his son Adam Pavel are deposited in SOA Třeboň, subsidiary Jindřichův Hradec, RA Slavatů, inv. č. 130, sign. III C 2a, kart. 23-24. On Adam Pavel Josef Hrdlčka, Synové „velkých“ otcư. Videňský dvưr očima Adama Pavla Slavaty, in: Václav Bůžek Pavel Král (edd.), Šlechta v habsburské monarchii a císařský dvůr (1526-1740), České Budějovice 2003 (= Opera historica 10), pp. 249-273.

50 Zdeněk Kalista, Slavatovský italský kopiár̆, Jihočeský sborník historický 35, 1966, pp. 193-198. 
been bound, the books were equipped with pencil pagination in left bottom corners of the page, numbering also the title of each book. However, the pagination is not continual in all ten books. Continual pagination was carried out in the first five books and then again in other five.

The first and most extensive book contains drafts of Slavata's correspondence to Bohemian nobles from 1622 to 1646. The second draft book compiles quaternes of letters to Czech noblemen from 1629 to 1632 . The third book covers the same time period and is labelled with the adjective "German" because it includes drafts of German letters of Vilém Slavata. The fourth book from 1630 to 1639 was used for letters which were addressed to Adam of Valdštejn, Adam Pavel Slavata, Přibík Jeníšek of Újezd, Jaroslav Bořita of Martinice and his son Jiří Adam. The fifth book is in Italian with drafts from 1631 to 1634. The sixth draft book contains letters to Jaroslav Bořita of Martinice and other Czech noblemen from 1631 to 1648 . The seventh draft book includes letters which were sent to high administrative officers of Slavata family manors, mainly to Regent Jan Unčovský of Rozenport and Supreme Hetman Hynek Ladislav Vejmiler of Vejtmile from 1631 to $1637 .{ }^{11}$ The next book is dedicated to drafts of letters for Adam Pavel Slavata from 1631 to 1650 and the ninth draft book includes in vast majority correspondence with the above-mentioned officer Hynek Ladislav Vejmiler of Vejtmile between 1634 and 1637. The last book lists drafts of letter which Vilém Slavata mainly addressed to Jiří Adam Bořita of Martinice from 1634 to 1644.

When summarising exploitation and utilisation of Slavata's letters in modern historical scholarship it is actually possible to repeat the words of $Z$ deněk Kalista, who more than forty years ago wrote, "[s]ouboru nebylo dosud v naši ani cizi bistorické literatuře použito [...the collection has not been used in our historical literature so far]. "52 Of course, there are exceptions. ${ }^{53}$ Probably the first historian who worked with the draft books for a longer period time, though not systematically, was the

51 On him Jiří Kubeš, Vilém Slavata a jeho hejtmani. Kanatomii prestiže raně novověké šlechty, Historický obzor 12, 2001, pp. 70-75; Josef HrDLIČKA, Mezi ctí a normou. Ke kultuře služby slavatorských hejtmanů okolo roku 1630, in: Václav Bůžek - Pavel Král (edd.), Společnost v zemích habsburské monarchie a její obraz v pramenech (1526-1740), České Budějovice 2006 (= Opera historica 11), pp. 347-373.

Z. Kalista, Slavatovský italský kopiár̆, p. 193.

53 Notes in the letters document that they were utilized by scholars. Blue pencil underling is the most typical. According to Zdeněk Kalista and also to Jindřichův Hradec archivist Karel Tř́ska, František Dvorský, who utilized the draft books for his book on Albrecht of Valdštejn, carried out these interventions (František DvorskÝ, Historické doklady k zámérům Albrechta z Valdštejna a jeho spojenců, Praha 1867); Zdeněk Kalista, Slavatovský italský kopiár footnote 2, p. 193. Another researcher who knew the draft books very well and worked with them was without any doubt a Černín archivist and regional historian František Teplý. In his extensive book on the history of Jindřichův Hradec he dedicated one volume to the period of Slavatas (1604-1691); František TePLÝ, Déjiny mésta Jindřichova Hradce I/3. Slavatové v Jindř. Hradci (1604-1691), Jindřichův Hradec 1935. 
Černín archivist František Tischer. In the 1880s, he did a serial selective edition of 84 letters of Vilém Slavata addressed to Jaroslav Bořita of Martinice and his son Jiří Adam from the early 1630s for a newly established historical journal Sbornik bistorický. Nevertheless, he did not rewrote the letters in extenso, nor he commented on them in any way. ${ }^{54}$

Another treatment of the drafts did not appeared until eighty years later. The above-mentioned Zdeněk Kalista excerpted the Italian draft book from 1631 to 1634 into a short essay. ${ }^{55}$ Mostly, it is Slavata's correspondence written in Italian completed with so called avisa, i. e. written news from some Italian cities, mostly from Venice, about contemporary European events. Together with these Italian relations it also contains smaller number of similar German news, mostly describing three events from the beginning of the 1630s. The first one was the Battle of Breitenfeld of September 1631 and the following events. The siege of Prague by the Saxon army at the break of 1631 and 1632 was the most important among them, both for the Czech lands and for the correspondence of Vilém Slavata. ${ }^{56}$ The third set of news is connected with the siege of the Swedish garrison in Regensburg by imperial and League armies in summer 1634 .

Kalista's paper was the last work with the draft books for a long time. Once more, in the late 1990s, they attracted the attention of historians who were interested in the early modern nobility. Petr Mata researched the political career of Vilém Slavata and his position and influence at the imperial court in Vienna, ${ }^{57}$ Pavel Král focused on the voiding of the marriage of Adam Pavel Slavata and Maria Margaretha of Eggenberg. ${ }^{58}$ Josef Hrdlička utilised the draft books for his research of administrative structure of Slavata family manors, ways of communication at the dominion and the course of

54 František Tischer (ed.), Dopisy Viléma hraběte Slavaty Jaroslavu Bořitovi hraběti z Martinic z let 1631 a 1632, Sborník historický 1,1883, pp. 305-322; IDEM, Dopisy Viléma hrabète Slavaty Jaroslavu Bořitovi hrabèti z Martinic z léta 1632, Sborník historický 2, 1884, pp. 32-37, 92-98; IDEM, Dopisy Viléma hrabète Slavaty psané Jaroslavu Bořitovi hrabèti z Martinic a jeho synovi z let 1633 a 1634, Sborník historický 3, 1885, pp. 193-202, 383-292, 360-364; IDEM, Dopisy Viléma hrabète Slavaty Jaroslavu Bořitovi hrabéti z Martinic a jeho synovi z roku 1635, Sborník historický 4, 1886, pp. 352-363.

55 SOA Třeboň, subsidiary Jindřichův Hradec, RA Slavatů, inv. č. 102, kniha č. 19.

56 Antonín Reze к, Dèjiny saského vpádu do Čech (1631-1632) a návrat emigrace, Praha 1889; Miroslav Toegel, Príćiny saského vpádu do Čech v roce 1631, Československý časopis historický 21, 1973, pp. 552-581.

Václav BŮŽEK - Josef HrduIČKa - Pavel KRÁL - Zdeněk VYBíral, Věk urozených. Šlechta v českých zemich na prahu novověku, Praha-Litomyšl 2002, mainly pp. 335-336; Pavel KráL, Konec manželství Adama Pavla Slavaty z Chlumu a Košumberka a Marie Markéty z Eggenberku, Opera historica 16, 2015, pp. 185-206. 
re-Catholisation..$^{59}$ Despite rather small attention have been paid to the draft books so far, it is possible to repeat words of Antonín Rezek which he wrote more than a hundred years ago when working on another manuscript: „všechno, co [...]

Vilém Slavata sepsal, objevuje se býti pri kritickém zkoumání historickým pramenem proní rady, jak co do vèrohodnosti, tak co do rozsáblosti poskytnutébo materiálu [when critically studied, everything what was written by Vilém Slavata seems to be historical sources of the greatest importance as far as their credence and extent are concerned] ". 60

There is a lot of information about crucial issues of Czech and (central)-European history of the early $17^{\text {th }}$ century in the drafted letters of Vilém Slavata, who was a leading Bohemian politician of the time and a regular participant at the court of Emperors Ferdinand II and Ferdinand III. Nevertheless, the following text does not aim to list all of them; rather, it briefly outlines topics which the editors consider to be typical at the present state of the editing process. In the first place, these are the abundant commentaries on contemporary, crucial or marginal, political, military and other events and decisions at monarchic or even European level witnessed by the High Chancellor. The drafts of the letters reveal circumstances and ways in which these decisions were reached in the centres of the contemporary politics, and thus are priceless for rendering decision-making mechanisms at the imperial court as the centre of power of the world of the period. The drafts define the circle of persons with who Slavata was in a regular written contact and consulted politics. They also bring his reflection of other distinguished representatives of politics, the Church, army, of his political opponents and enemies. The correspondence also describes relations in the family of Vilém Slavata, above all his attitude to his sons Adam Pavel, Jáchym Oldřich (1604-1645) and Ferdinand Vít (1605-1645), for whom Slavata tried, unsuccessfully, obtain positions at the imperial court. Officers from family manors in south, central and east Bohemia were among addressees of the letters. Thus, it is possible to follow the events which occurred in the rural areas of the country during the Thirty Years' War. It also shows how the High Chancellor tried to control his enterprises, how he attempted to secure safety and peace at the family seats or how his Vienna house was supplied. Last but not least, the correspondence shows a leading politician running his office.

There are basically tree main reasons why to make the drafted correspondence of Vilém Slavata accessible in the form of a critical scholarly edition. First, it is a unique collection of letters, as far as their extent and significance are

59 Besides above cited works also Josef HRDLIČKA, Herrschaftliche Amtsträger als Klienten und Patrone im frühneuzeitlichen Böbmen? Kommunikation im Dominium der Herren von Neuhaus, Slawata und Tschernin (1550-1730), in: Stefan Brakensiek - Heide Wunder (edd.), Ergebene Diener ihrer Herren? Herrschaftsvermittlung im alten Europa, Köln-Weimar-Wien 2005, pp. 145-163.

60 A. Rezeк (ed.), Zápisky, p. 3. 
concerned. Second, the author was a key and extraordinary influential player on the Czech political scene, active long-term in the contemporary centre of powerthe imperial court of Ferdinand II and Ferdinand III. This was unmatched by any other Bohemian noblemen of the period. Third, Vilém Slavata was nearly a "graphomaniac" who spent each free moment by dictating treatises and letters to various addressees. Moreover, the letters originate from an extremely dynamic period of the latter quarter of the $17^{\text {th }}$ century, from the time of the Thirty Years' War, when the foundations of the new political and religious situation developed and were introduced into social praxis.

The project will make the above-mentioned ten draft books of letters by Vilém Slavata accessible in the form of a critical edition. As stated above, the drafts were not written into the books chronologically. However, the edition will apply the chronological approach and will present individual drafts organised on a time axis to future researchers. Each edited draft will be provided with a serial number, a Czech and German summary, the date and information about the archival storage. The German summary will make the content of the letters available to foreign scholars, especially to those who focus their research on the imperial court in Vienna. Czech letter will be transcribed, in German and Italian correspondence transliteration will be applied. Editing rules will be explained in edition introduction and will respect modern methods. ${ }^{61}$ The edition will be equipped with serviceable indexes of names, places and selected subjects.

61 Cf. Ivan ŠŤovíčEK et al., Zásady vydáváni novovèkých historických pramenů z obdobi od počátku 16. století do současnosti. Př́prava védeckých edic dokumentũ ze 16.-20. století, Praha 2002; IDEM, Edični teorie a metodika. Sbornik autorových textů vydaných k jeho životnimu jubileu, Praha 2008; Milan KорескÝ, K vydáváni literárnich památek 16. a 17. stoleti, Studia Comeniana et historica 7, 1977, pp. 7-22; Josef VINTR, Zásady transkripce českých textũ z barokni doby, Listy filologické 71, 1998, pp. 341-346. 
Josef Hrdlička - Pavel Král

\section{Draft Books of Vilém Slavata of Chlum und Košumberk (1572-1652). A Publication Project (Abstract)}

The main aim of the paper is to present an intention to publish the early modern aristocratic correspondence of Vilém Slavata of Chlum and Košumberk in a form of a critical edition. First, the study reviews scholarly editions of aristocratic letters in the Czech historiography. Then, it introduces the life and career of Vilém Slavata and gives brief information on his writings and personal papers. Later, it concentrates on ten draft books of the correspondence of Vilém Slavata. It summarizes exploitation and utilisation of Slavata's letters in modern historical scholarship and focuses on their origin, form and content. It also briefly outlines research topics included in the letters which the editors consider to be typical at the present state of the editing process and, last but not least, it gives basic information about editing rules.

KEY WORDS:

Nobility; Vilém Slavata of Chlum and Košumberk; draft books; correspondence; early modern; edition 